\title{
The Conceptual Framework for Analyze Efficiency in Land Tax Administration System
}

Siti Norfaizah Sahari, Salfarina Samsudin, Robiah Suratman

To Link this Article: http://dx.doi.org/10.6007/IJARBSS/v11-i1/9016

DOI:10.6007/IJARBSS/v11-i1/9016

Received: 07 December 2020, Revised: 08 January 2021, Accepted: 17 January 2021

Published Online: 23 January 2021

In-Text Citation: (Sahari et al., 2021)

To Cite this Article: Sahari, S. N., Samsudin, S., \& Suratman, R. (2021). The Conceptual Framework for Analyze Efficiency in Land Tax Administration System. International Journal of Academic Research in Business and Social Sciences, 11(1), 938-956.

Copyright: (c) 2021 The Author(s)

Published by Human Resource Management Academic Research Society (www.hrmars.com)

This article is published under the Creative Commons Attribution (CC BY 4.0) license. Anyone may reproduce, distribute, translate and create derivative works of this article (for both commercial and non-commercial purposes), subject to full attribution to the original publication and authors. The full terms of this license may be seen at: http://creativecommons.org/licences/by/4.0/legalcode

Vol. 11, No. 1, 2021, Pg. 938 - 956

Full Terms \& Conditions of access and use can be found at http://hrmars.com/index.php/pages/detail/publication-ethics 


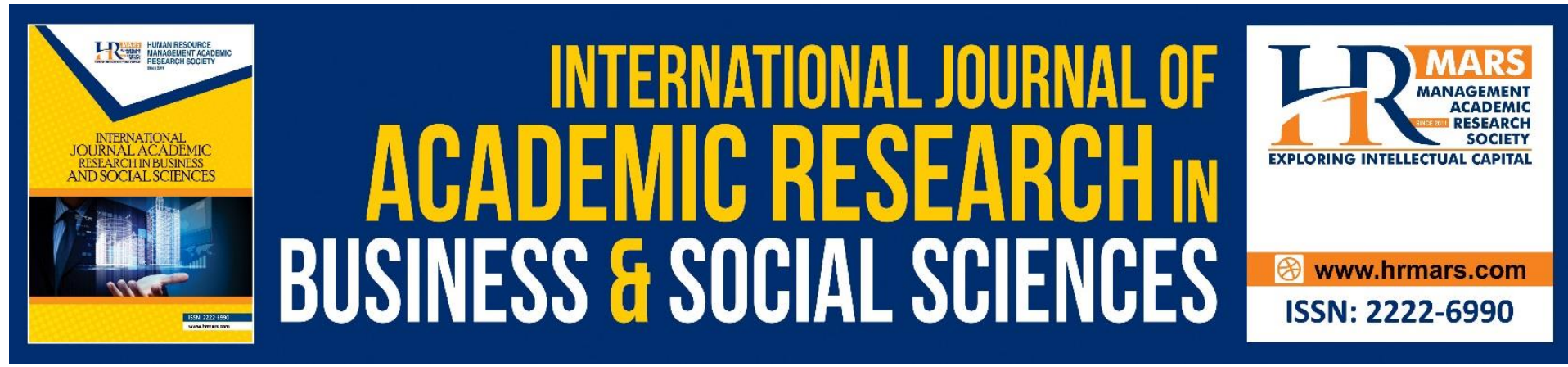

\title{
The Conceptual Framework for Analyze Efficiency in Land Tax Administration System
}

\author{
Siti Norfaizah Sahari, Salfarina Samsudin, Robiah Suratman \\ Department of Real Estate, Faculty of Built Environment and Surveying, Universiti Teknologi \\ Malaysia, 81310 Skudai, Johor Malaysia
}

\begin{abstract}
This paper aims to develop a conceptual framework of land tax administration and collection efficiency that can be used to analyze and discuss tax performance. Relevant literature was sourced using keywords pertaining to tax administration, tax collection and tax efficiency variables to identify the constructs of the framework. The paper then developed and proposed a conceptual model to study the efficiency of land tax system by land administration institutions. The findings revealed that eighteen elements of land tax administration and collection efficiency were identified, namely, administrative strategy, awareness creation, comprehensive assessment, compliance strategy, anti- corruption practice, human resources management, monitoring and evaluation, law enforcement, leadership style, private participation, public enlightenment, rules and regulations, service delivery, tax audit practice, tax agencies, collection strategy, use of ICT, and tax reforms and amendment. The proposed conceptual framework may assist future research in providing a structured approach for assessing tax administration and collection performance. The framework may also assist tax authorities in designing strategic planning to improve the land tax system. An acceptable and specific measurement of tax administration and collection efficiency has been proposed and tested as a tool for analyzing and discussing land tax performance variables. This framework can help policy makers to think about the right combination of strategies in specific contexts. Keywords: Efficiency, Finance, Land Tax, Malaysia, Revenue.
\end{abstract}

\section{Introduction}

It has become increasingly demanding for all governments the world to devise appropriate means of generating adequate revenue to finance government expenditure which continues to soar as a result of growth in population and economic development. This is the reason that taxation has become legally accepted all over the world as one of the most suitable means of revenue raised. Seligman (1916) as cited in Sahari et al., (2020) defines tax "is a compulsory contribution from the person to the government to defray the expense incurred in the common interest of all without reference to special benefits conferred". Sommerfeld, Anderson and Brock (1981) defined a tax as "non-penal yet compulsory transfer of resources from private to the public sector, levied on the basis of predetermined criteria and without reference to specific benefits, so as to accomplish some of a nation's economic and social objectives. Again, The World Bank goes beyond the traditional definition of a tax and defines 
it to include involuntary fees levied on corporations or individuals as well as unrequited payments to the general government (Djankov, Ganser, McLiesh, Ramalho \& Shleifer, 2010).

Taxation is a crucial macroeconomic policy instrument to all country, especially to developing countries like Malaysia. A tax is usually a percentage levied on incomes, sale prices, property values and so on. Taxation, apart from generating revenue for government expenditure where it contributes to ensure social justice and reduce the inequalities of income and wealth in the economy. Tax can be defined simply as a payment to support the cost of Government involves the transfer of money from individuals to Governments. On the other hand, taxes are not voluntary but compulsory; thus, anyone subject to a tax is not free to choose whether or not to pay. In recent times, governments have resorted to strengthening of the tax collection as a mean of fixing their economies in the face of the global economic breakdown. As such various methods have been put in place to mobilize internally generated funds through taxation such as direct tax and indirect tax.

\section{Land as a Source of Revenue}

"Land" can be understood in many ways. According to Ratcliffe (1976) Rousseau says that land as the foundation of any social system that leads to the formation of civil society and social inequalities. According to Dale and McLaughlin (1999) land seen as property or immovable property which includes all things attached to it such as buildings and other permanent fixtures. Again, land is referred to the surface of the earth, the materials beneath the air above and all things fixed to the soil (Sahari et al., 2020; Sahari \& Samsudin, 2019; Sahari et al., 2020). In the same way, the definition of land by the Australian Government's Overseas Aid Program (2001) including the structures and the improvements thereon. In Malaysia, Under Section 5 of the National Land Code (NLC) 1965, land is said to be the surface of the earth and all substances forming that surface. These definitions primarily determine the physical characteristics of the land.

In an economic perspective, land was seen as a factor of production which was a huge interest. Ratcliffe (1976) pointed out that land is the foundation of all economic production when its uses can be diversified as the need of mankind rises. Usually, land is considered as a factor of production in much the same way as labour, capital and enterprise but with certain features that distinguished it. Besides, land also rightly referred to the original source of all material wealth because the value of land can be used as a source of wealth, power, status and revenue (Williamson, Enemark, Wallace \& Rajabifard, 2010). Furthermore, land value is a symbol of wealth in any society where individuals or communities have rights of ownership and use, at the same time it can be bought and sold, therefore land could be taxed accordingly to become a key source of revenue for local and national governments (Sahari et al., 2020). Thus, land is seen as a source of revenue to the country and economic production resources which are important and need to be reminded that this land is a scarce resource. The scarcities of land have been pressured by Ratcliffe (1976) is when the land is absolutely considered as irreplaceable for no one piece of land like any other. Land has some unique characteristics, wish distinguish it from other goods in the economy and make it a good revenue source for revenue generation by a Government (Sahari, Samsudin, Bujang \& Jiram, 2018). These can be summarized as shows in figure 1 : 
Figure 1. Characteristics of land (Source: Author's).

These characteristics make land a unique resource for a government especially for the local government such as Malaysia. Section 5 of NLC 1965 has defined land revenue as: ..."any annual sum payable to State Authorities by way of rent; any other annual payment due to the State Authorities which by any written law is to be collected as if it were rent or land revenue; and any fee due to the State Authorities in respect of arrears of rent by virtues of rules under Section $14^{\prime \prime} .$. The benefits from land holding are often locally based and thus accessible to

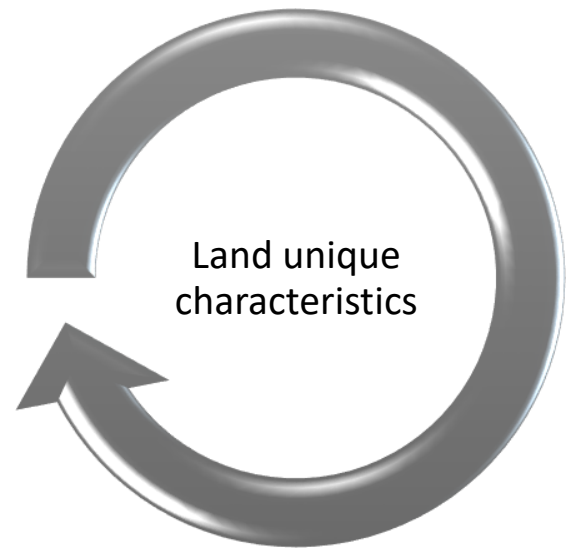

- Store of value and a basic for saving

- Limited in supply

- Means of production, hence a store of wealth

- Physically nondepreciable and not influence by time

- Fixed in location

the local authorities, not only for taxation purposes but also for enhancing the living conditions of the local people through spatial and economic planning. In Malaysia, land tax as a key contributor that brings substantial revenue to almost all the states in Malaysia. It is regarded as one of the largest single internal sources of state revenues and this is collected by state governments through their respective land administration system machinery for example the land offices. Land tax is imposed on the registered proprietors of land to be or alienated land. The power to collect land tax is derived from the NLC 1965 as well as from the respective State Land Rules (SLR). As land is considered a form of wealth, land owners who own a lot of lands are perceived to be wealthy people, thus, land tax is regarded as a tax on wealth. However, the amount of land tax imposed on a piece of land is based on physical factors such as the category of land use, location and size. The method of determining the amount of this tax is completely different from other property taxes (Sahari et al., 2020).

Available statistics from the National Audit Department (NAD) indicates that Government obtains $75 \%-80 \%$ of its revenue for expenditure from direct taxes including land tax (Sahari et al., 2020). From a historical perspective, property tax was an ancient way of taxing wealth. Land tax was considered as a means of personal taxation. In ancient economics, which were agricultural in nature, land values or produce was the best available measure of the taxpaying capacity of a citizen. But as modernization sets in, land tax more and more lost its place as the main source of revenue due to lack of attention (Sahari \& Samsudin, 2019). With proper attention, land tax can regain its significance as major source of revenue.

In Malaysia, the revenues from land are assigned to States (Item Two of Part Three of the Tenth Schedule). The National Land Code (NLC) 1965 is the source of power and was formulated to create uniformity of law and policy relating to land includes land tenure, land registration, dealing and collection of land revenue in particular in the eleventh States in Peninsular Malaysia. Under the National Land Code, Act of 1965 empowers the State 
Authority, among other things, to collect land revenues. One of the sources of land revenues is the annual land tax, or the quit rent, as it is widely known. Accessible statistics from the National Audit Department (NAD) in 2017 indicates that State government obtains 16.6\%$31.5 \%$ of its revenue from land tax.

Even though land tax forms an important source of state revenues, the record shows that state land administrations in Peninsular Malaysia have encountered numerous problems regarding its collection and constrained by limited sources of income, notwithstanding the total amount received, revenues from land form a significant contribution to the State coffers.

Table 1. Revenue of land tax in Malaysia

\begin{tabular}{|l|l|l|l|l|l|l|}
\hline \multirow{2}{*}{ Year } & Current Land Tax & \multicolumn{4}{|l|}{ Outstanding Land Tax } \\
\cline { 2 - 7 } & Targeted & Received & $\%$ & Targeted & Received & $\%$ \\
\hline 2009 & RM256,069,739 & RM203,521,825 & 79.5 & RM103,475,435 & RM18,504,889 & 17.9 \\
\hline 2010 & RM254,292,673 & RM207,687,281 & 81.7 & RM104,677,078 & RM20,391,366 & 19.5 \\
\hline 2011 & RM265,397,099 & RM219,199,070 & 82.6 & RM96,798,282 & RM33,339,894 & 34.4 \\
\hline 2012 & RM262,249,504 & RM237,877,511 & 90.7 & RM74,230,136 & RM31,661,585 & 42.7 \\
\hline 2013 & RM307,783,045 & RM254,380,967 & 82.7 & RM81,073,931 & RM20,746,818 & 25.6 \\
\hline 2014 & RM310,588,413 & RM257,512,041 & 82.9 & RM84,555,334 & RM21,611,375 & 25.6 \\
\hline 2015 & RM320,992,960 & RM286,792,763 & 89.4 & RM89,212,689 & RM31,235,064 & 35.0 \\
\hline 2016 & RM334,779,764 & RM307,219,031 & 91.8 & RM81,026,361 & RM22,556,660 & 27.8 \\
\hline 2017 & RM379,407,457 & RM347,530,487 & 91.6 & RM88,741,106 & RM25,427,864 & 28.7 \\
\hline Total & RM3,093,600,653 & RM2,668,517,194 & 86.3 & RM869,183,351 & RM243,149,426 & 28.0 \\
\hline
\end{tabular}

(Adapted from the summary of financial statements, Malaysia National Audit Department, 2018).

Over the years, revenue from this land tax has failed to meet their collection targets and also failed to make any significant contribution to total tax revenue. Records from the summary of financial statements and financial management of agencies, Malaysia National Audit Department indicate that from the period 2009 to 2017 (see table 1), a period of nine years, land tax contributed a total of $86.3 \%$ to total revenue mobilized to State revenues. Expectations from total tax revenue keeps rising from a target of RM203,521,825 (79.5\%) in 2009 to RM347,530,487 (91.6\%) in 2017, but the contributions of outstanding land tax remain negligible. The total of outstanding tax keeps accumulating every year even though various efforts have been made to overcome the problems. The total continuously grows annually and it's seen as weakening the State government treasury. Finally, in most of the years, the land offices not have been able to collect the targeted total of outstanding land tax. The trend shows they only managed to collect less than $42.7 \%$ of the outstanding land tax targeted. The uncollected targeted total of outstanding will subsequently add to the annual accumulated outstanding land tax that already high. This trend signals a need to improve the present system of land revenue collection. Therefore, the study seeks to examine ways in which land tax administration could be made more efficiently to raise more revenue for the State government and to present a conceptual model on tax efficiency system of land administration institutions that are responsible in administering and collecting land tax in Malaysia. 


\section{Literature Review}

\section{The Definition of Efficiency}

In recent years, the debate of the role of public sector has shifted towards understanding and measurement of efficiency and effectiveness. According to Bartuševičienè and Šakalytė (2013) efficiency and effectiveness are central to the measurement of organizational performance. Despite this obvious relevance of measuring organizational performance, it appears that most organizational managers and individuals believed that efficiency and effectiveness are the same. However, each of these terms has their own distinct meaning. Leibenstein (2011) stated that the efficient or efficiency was originally developed and refined by economists who still defined efficiency as the relationship between the inputs into a system (be it agriculture, industrial or tax) and the outputs from that system (be they wheat, vehicles or revenue collection). In public administration, view of some scholar such Diesing (1973) efficiency can be defined as the maximum achievement of a given end with given resources, thus it includes within itself the values of maximization and achievement, Waldo (1984) defines the efficiency by calculating the ratio of the effects actually obtained with the available resources to the maximum effects possible with the available resources (Sahari \& Samsudin, 2019). Again, according to Sahari and Samsudin (2019) efficiency measures relationship between inputs and outputs or how successfully the inputs have been transformed into outputs.

In tax administration context, a tax administration system is regarded as efficient if it can cause little or no interferences in the functioning of an economy (Sahari \& Samsudin, 2019). View of some scholar explained about efficiency such as Leibenstein (2011) they explained that efficiency is the "relationship between the cost and the expedience of transforming inputs into outputs". They opined the proper administration of resources must be taken into account as far as public resources are concerned. Auerbach and Hines (2002) efficiency is doing things right and relating them to input and what a manager does. They state that to be efficient, one must therefore attend to the input requirements of the job to clarification of objective, planning, direction and control. It is making the most economic use of resources. Vlassenko (2001) explained efficiency in tax administration system means that the system should be able to raise large amounts of revenue in a short time and at relatively low cost. Otherwise, the tax system should collect the maximum revenue which is there should be minimum losses through non-payment and excessive or inefficient administration.

According to the OECD (2011) tax administration efficiency reduces costs while providing better services to citizens and businesses. The OECD further asserts that efficiency depends

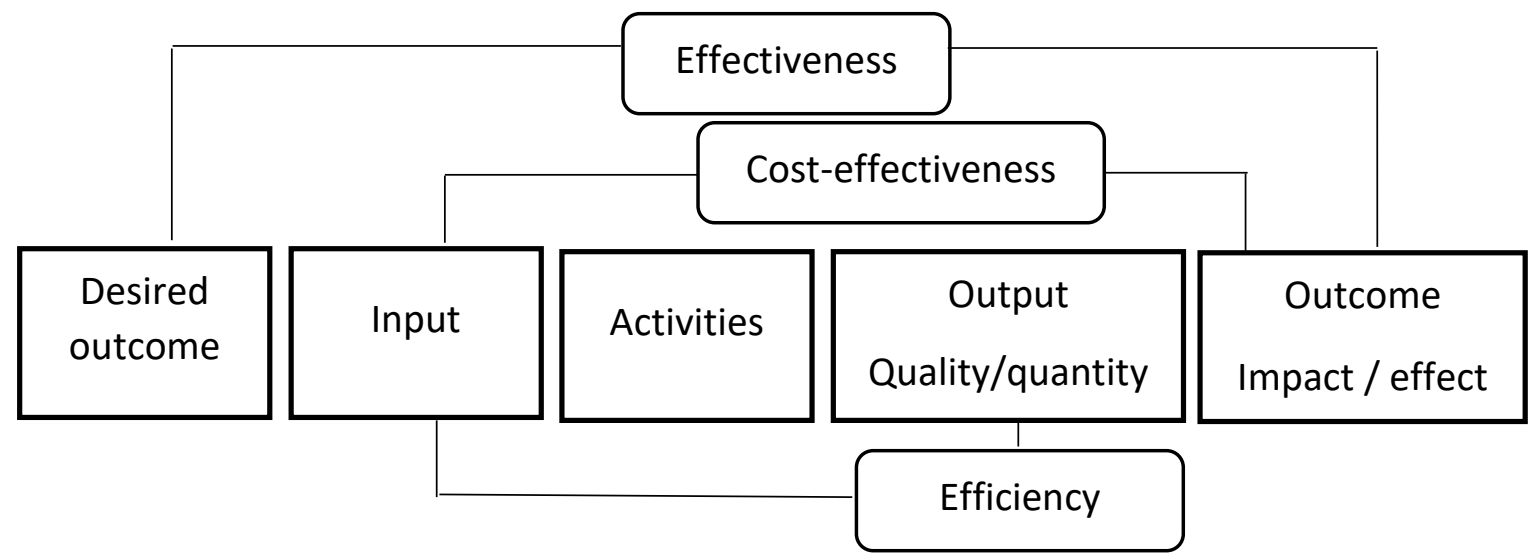


on how organizations design their internal organizational structures, how well they allocate their budgeted funds to meet their needs, how they utilize ICT to save costs and how they determine the levels and remuneration of their employees. Kayuza (2006) expressed the opinion that tax efficiency involves using the least resources to achieve maximum tax collection output and attaining higher productivity in tax collection mechanism. This includes closing the tax collection quality gab in terms of competence, courtesy, communication, reliability, responsiveness, credibility of tax officials which all aid customer satisfaction measurement. These taxpaying institutions and individuals need to be treated with care, respect and dignity. They are therefore considered as strategic partners of the tax division. He opined that taxpayer satisfaction is the core business of tax efficiency. In simply defining the efficiency of tax administration (see figure 2), efficiency simply as measures assess the relationship between outputs and the inputs used to produce them; cost effectiveness measures evaluate outcomes as a proportion of the total inputs required to produce them; and effectiveness measures assess the whole sequence in terms of how it achieved the intended objectives or outcomes.

Figure 2. Expanded Logic Model Sequence (Sources: Australian Taxation Office, 2007).

In this model, the relationship among the process of inputs, activities, outputs, and outcomes is clearly projected, together with how this process relates to the efficiency and effectiveness in the tax administration system. Within this model, efficiency measures reflect the relationship between outputs and inputs used to produce them, while effectiveness measures reflect the outcomes achieved against the desired outcomes. On the other hand, efficiency measures the relationship between input and output or how organization can maximize the use of available resource to achieve maximum output. For this study, efficiency is considered to be how successfully organizational inputs are transformed into outputs. In this context, efficiency is the optimization of government resource (tax administration activities) to provide qualitative service (output) such maximum tax revenue.

\section{Factors that Negative Impact on Efficiency of Tax Administration}

The main objective of this part is to discuss factors that can provide explanation for the occurrences of inefficiency in tax administration performance. Based on the reviews of literature, several factors were identified to explain the factors that directly impact on tax administration provide from many scholar and institution endorsed. However, additional literature in this part that has no direct relation to tax have been useful in helping to understand the various contexts of tax administration issue.

The fundamental goal of any revenue authority is to collect taxes and duties payable according to the law. However, there are many factors inefficiency that constraint to financing a government (State and Local) expenditure and development (Sahari et al., 2020). The heavy reliance on government sources has made it very difficult to see it as a need to increase internal revenue mobilization efforts. The amount of revenue raised and spent through taxes internally is depended on the amount of transfer of payments from higher tiers of government. Alias (2002) sees the taxes levied and collected at the local government level as unyielding as compared to those accessed by the central government. This situation has limited the ability of the local government to mobilized adequate revenue for development. 
Efficiency and effectiveness have an impact on the overall performance of a tax administration (OECD, 2011). The OECD defined tax administration as government activities, includes the provision of public services, rely on taxes collected from citizens and business. Tax administration comprises of all the strategies and principles adopted by the government in order to plan, impose, collect and account for taxes, as well as to coordinate and monitor staff those who are charged with the responsibility for taxation (Akintoye \& Tashie, 2013). An efficient and effective tax administration is a key determinant of investment climate, which it helps to attract more investment, reduce poverty and increase growth. Besides, it also enables the government to raise revenue with lower tax rates. The main role of a tax administration is to collect tax revenue. The efficiency of a tax administration is best evaluated by looking at its tax collection process as noted by (Akintoye \& Tashie, 2013).

The findings by Baurer (2005) conducted a comprehensive study on tax administration operations in developing countries and revealed there are varies factors that cause inefficient and ineffective in the tax collection process which are cover poor management practices, taxpayer registration, enforcement, operating procedure, taxpayer education, employee training, information technology and performance evaluation and control. Finding from case studies in Tanzania by Shemdoe (2015) described weakness in tax administration operations in Kerala Region which cover intentional tax evasion from taxpayer, lack of staff in revenue action, corruption practice by officials, political pressure, high compliance cost, poor financial records and poor knowledge on potentiality of various sources of revenue. Anyaduba (2018) in his study of the Nigerian tax system pointed out that most of the tax offices do not have the internal control system to perform the supervisory roles. This has resulted in the lack of monitoring and effective control of the revenue collected and administration operation. He claimed that the success or failure of the tax system especially in tax policy implementation is dependent significantly on the efficiency and effectiveness of these tax administrators. In Libya, according to the Libyan Audit Bureau Report issued by Libyan Audit Bureau as cited in Sahari and Samsudin (2019) there are numerous internal and external factors for inefficient and ineffective tax administration and collection such lack of power in tax department, poor leadership style, lack of modernization in use ICT and inadequate training for employees.

Ogbonna and Ebimobowei (2012) figured out that lack of motivation and training as key factors affecting the tax administration and collection. Pommerehne and Hannemann (2004) argued that the efficiency in tax administration hugely relies on motivation, ICT, training and leadership. In case of Malaysia, the findings by Al Fahmey Abdul Rahim (2010) conducted structuration theory on sources of tax arrears in the case study in Perak and found weakness that impact on efficiency and effectiveness of tax administration performance which cover two main aspect such aspect of resources (lack quality of human resources, lack of tax information, absence of administrative will, defects in ICT system, lack of leadership, insufficient human resources and inadequate financial resources), aspect of rule (inappropriate laws of land attributes and outdated provision of formal rules) and other factor include the attitudes. Similarly, researcher such as Alias (2002) the inefficiency was due to factors such as lack of personnel, inadequate qualified staff, attitude of ignoring the presence of legal tools, outdated records and the general economic situation.

Lack of transparency by taxpayer is one of the key factors that cause inefficiency in tax administration and tax collection which ultimately leads to tax evasion or avoidance. Tax 
evasion defined as failure to pay taxes imposed on individuals or businesses by public authorities. Tax evasion is the use of legal methods to enable in changing the tax system utilization to reduce current or future liabilities. It involves imposing artificial transactions to benefit from taxes (Sahari \& Samsudin, 2019)

Corruption is another factor influencing inefficiency in tax administration and collection and is practiced in different forms such as services that should be free are charged or to help taxpayers with complicated procedures the tax officials charge them or to get tax exemption qualification the tax officials charge the tax payers, failing to assess the non- registered businesses, smuggling of goods into the country, overstating values, under assessing tax to importers and tax payers and loosing files (Alm, Martinez \& McClellan, 2016). According to Alm, Martinez and McClellan (2016) corrupt practices in tax administration involves tax officers, taxpayers, importers and customs clearing agents.

To maintain and ensure the efficiency in tax administration and collection revenue, both need sufficient time, efforts, human and financial resources. Gill (2000) indicated that skill level, numbers, experience, commitment and morale of the revenue administration members determine the success of the organization. Similarly, Noh (2008) stated that the land offices lack human resource in terms of numbers. He concluded that the situation is further worsened when the existing human resource is neither knowledgeable nor experience in tax laws. As a result, those efforts for improvements will lose momentum and incur delays. Lack of resources poses serious administrative difficulties and has made the measurement of efficient tax bases not possible in certain cases. Financial resources in term $\mathrm{s}$ of budget allocation must be made sufficiently available to allow further improvement in other areas such as in the development and upgrading of ICT, human resources, physical facilities and so on. At the end of the day, failure to provide appropriate resources equate with targeted tax not being collected and the increase of the uncollected tax revenues.

A tax exemption is granted by the government of a country and it is one of the core factors which lead to inefficiency in tax administration and collection. Tax exemptions involve large sums of money. The amount of money which is involved raise question about the purpose incentives are serving and whether the amounts being spent on them are accounted. Large firms often make use of this tax incentive mechanism to avoid paying taxes. Developing countries are eager to attract investment in their countries thus they grant exemptions to large firms as incentive to boost investment while other large firms see this as a loophole to avoid paying taxes (Gauthier \& Reinikka, 2006).

According to Connolly and Munro (1999) ideological position of those in power is reflected in the tax system. The government of the day reflects its political philosophy in the tax policy making. Hence, tax policy would reflect the culture, values, needs of the society as well as those hold the power. Gallagher (2005) found that the deterioration of Guatemala tax administration ranges from 1993 to 1994 to lack of enforcement due to lack of politic support. This was observed when political leaders failed to sustain reform as well as to provide support for enforcement as provided by law. The lack of support has led to constrained improvement on the revenue administration (Crandall \& Bodin, 2005). For instance, the influence of politics in the tax system is not limited to policy making process but it is also present in the enforcement aspect which reflects the political orientation of the party in power. 
According to Hastuti (2014) the opined that lack of education on tax responsibility is another factor influencing inefficiency in tax system. As with all taxes, attention should also be given to educate the taxpayer on the rationale, procedures, obligations and responsibilities related to the business licenses and property tax. Having the ability to link revenue collections to improved service delivery, and a better-educated taxpayer population will enhance compliance. Mobilizing the community through enhanced participatory budgeting and civic participation will engage the citizens and also facilitate enhanced revenue collection.

Additionally, the others factor that cause inefficiency in tax administration and collection performance can be elaborated in term of administration weakness, taxpayer problems and ICT problems. These factors are discussed as follow:

- $\quad$ Administration weakness

According to Whait (2012) opined that land administration staffs all over the world are not efficient in the way they organize their business due to improper planning. They lacked the skills in strategy development, ICT policy, information management and consequently not contributing to good management such as keeping registers and maps up-to-date. In support of that, Ding (2003) in his study on land policy reform in China revealed that land use taxes were difficult and costly to collect because of the lack of trained staff in land registration. As such revenue generated from land use taxes has not met expectations. Hussein (2006) in his analysis on the reform programmed of Malawi's local government indicated that adequate capacity and new administrative skill are required for the local authorities to discharge their responsibilities effectively. These rely upon the available infrastructure, the quality and the quantity of human resources and financial resources. The performance of the Malawi local government institution declined due to inadequate and inappropriate trained personnel. However, Tessema and Soeters (2006) found that major challenge for the government was to effectively use the expertise of the existing staff. They also argued that the main reason for the failure of the government development programmed, projects and routine operations is due to lack of competent civil servants. Therefore, the effective utilization of the trained staff could enable the civil service to function effectively.

\section{- $\quad$ Taxpayer Problems}

Crandall and Bodin (2005) pointed out that revenue administration must ensure a high level of compliance. Inefficiency due to compliance when it comes to the obligations imposed on them by law, taxpayers are not always compliant. Tax compliance, simply means adherence to tax reporting requirements; that is, that the taxpayer files all required tax returns at the proper time and that the returns accurately report tax liability in accordance with the tax laws, regulations, and court decisions applicable at the time the return is filed (Kirchler \& Wahl, 2010). According to Sapiei, Abdullah and Ismail (2013) a compliant taxpayer is one who fulfills every aspect of their tax obligations including registering with the revenue authority as required, filing the required returns on time; accurately reporting tax liability (in the required returns) in accordance with the prevailing, legislation, rulings, return instructions and court decisions, paying any outstanding taxes as they fall due; and maintaining all records as required. Non-compliance, on the other hand, signifies failing to meet tax reporting requirements. Non-compliance represents the most inclusive conceptualization with respect to the failure to meet tax obligations, whether intentional or unintentional (Crandall \& Bodin, 
2005). Other terms used to describe tax non-compliance include tax evasion, cheating, errors and misreporting (Remali et al., 2015).

According to Kasipillai, Baldry and Rao (2000) non-compliance may take four main forms such as failure to submit a tax return, understatement of income, overstatement of deductions, and failure to pay taxes by the due date. Saad (2014) account reasons for non-compliance due to the complexity of tax legislation, the complications in the procedures that a taxpayer must follow in order to pay taxes, unsatisfactory treatment of taxpayers by tax official, taxpayer's ignorance of the benefits derived from public revenue and negative image of public administration. Crandall and Bodin (2005) expressed the opinion that the issue of noncompliance is deteriorating in developing countries. They also assert that this is mainly due to public attitude towards government institutions, structure of tax rates, laws and public perception towards the provision of quality public services. Sindzingre (2007) argues that taxpayers in the least developed countries do not trust the credibility of the government management of finance and taxation systems and therefore reluctant to pay taxes. For tax authority to enjoy public confidence, it needs to be seen as credible and committed. Very serious efforts are needed to identify critical compliance risks as well as to develop effective compliance strategies in order to ensure non-compliance by taxpayers is reduce.

\section{- ICT Problems}

Generally, ICT is used to enhance performance in revenue administrations by reducing human error and processing times, providing readily accessible data for tax officers, promoting voluntary compliance thereby minimizing tax evasion and facilitating better decision making by tax authorities. According to Nyambo as cited in Chatama (2013) ICT help to maintain consistent record keeping, timely access of such records, fast processing of return which together improved the performance of tax revenue. In support of that, Bird and Zolt (2008) posed that ICT technologies are used to speed up the decision making process and Machupa, Otaigo, Koloseni, and Shimba (2011) claimed that computers facilitate service delivery, customer satisfaction, information accessibility, efficiency and effective administrative gain as well as information sharing among various units of the government. Based on these reviews, it is found that the ICT problem includes new technologies was not supported by state/district because of the cost, new technologies implemented were complex, installation and maintenance of new technologies challenge, employee's perception towards the technologies were negative and users not well trained to use the technologies.

\section{Review on Efficiency Factors for Successful in Tax Administration}

The main objective of this part is to discuss several factors that can improve and enhance the efficiency of the tax administration and collection performance as a whole in the tax system. Based on the reviews of literature, several criteria were identified that directly impact provide from many scholar and institution endorsed. Some researchers have suggested several steps for improving performance of the tax administration and collection. Based on reviews of literature, table 2 provides several factors efficiency for tax administration performance improvement from various researchers. In summarizing the findings, it can be said eighteen criteria that can help to improve and enhance the performance in the tax administration. The eighteen criteria as efficient are: 
Table 2. Efficiency factors for tax administration performance

\begin{tabular}{|c|c|c|}
\hline The factor & Explanation & $\begin{array}{l}\text { The summary based } \\
\text { on the ideas of }\end{array}$ \\
\hline $\begin{array}{l}\text { Tax } \\
\text { administrative } \\
\text { strategy }\end{array}$ & $\begin{array}{l}\text { - Reducing on recurrent expenditure costs for } \\
\text { administrative and compliance } \\
\text { - Simple tax design to keep at minimum tax evasion } \\
\text { and avoidance } \\
\text { - Improve capacity of tax officer and staff }\end{array}$ & (Whait, 2012) \\
\hline $\begin{array}{l}\text { Awareness } \\
\text { creation }\end{array}$ & $\begin{array}{l}\text { - Consultative session with society or other } \\
\text { influential individuals not only to taxpayers } \\
\text { - Taxpayers are fully informed about tax policies and } \\
\text { importance of compliance } \\
\text { - Improve public awareness by organizing various } \\
\text { programs, workshops about tax legal and policy }\end{array}$ & $\begin{array}{l}\text { (Chan, Troutman, \& } \\
\text { O'Bryan, 2000; } \\
\text { Yang, Ge, \& Barns, } \\
\text { 2011) }\end{array}$ \\
\hline $\begin{array}{l}\text { Comprehensive } \\
\text { assessment }\end{array}$ & $\begin{array}{l}\text { - Appropriates enforcement mechanism } \\
\text { - Appropriate audit performance } \\
\text { - Proper financial accounting system }\end{array}$ & $\begin{array}{l}\text { (Gallagher, 2005; Al } \\
\text { Fahmey Abdul } \\
\text { Rahim, 2010) }\end{array}$ \\
\hline $\begin{array}{l}\text { Tax compliance } \\
\text { strategy }\end{array}$ & $\begin{array}{l}\text { - Improve compliance with strongly to enforce the } \\
\text { law and increasing penalties } \\
\text { - Adequate staff to meet the challenges of tax } \\
\text { compliance } \\
\text { - Improve public education and awareness }\end{array}$ & $\begin{array}{l}\text { (Alabede, Ariffin, \& } \\
\text { Idris, 2011; Sapiei et } \\
\quad \text { al., 2013) }\end{array}$ \\
\hline $\begin{array}{l}\text { Anti-corruption } \\
\text { practice }\end{array}$ & $\begin{array}{l}\text { - Strong enforcement action against those accepting } \\
\text { or giving bribe } \\
\text { - Policies exist to prevent and identify corrupt } \\
\text { practices and favoritism } \\
\text { - Honest tax officers or staff }\end{array}$ & (Alm et al., 2016) \\
\hline $\begin{array}{l}\text { Human } \\
\text { resources } \\
\text { management }\end{array}$ & $\begin{array}{l}\text { - Training or workshop for the staff to sharpen their } \\
\text { skills to effectively and efficiently handle tax issues } \\
\text { - Improving HR conditions such as the availability of } \\
\text { well-qualified and well-motivated personnel } \\
\text { - Offer bonuses to improve staff work performance }\end{array}$ & $\begin{array}{c}\text { (Ganesh \& } \\
\text { Indradevi, 2015; } \\
\text { Ogbonna \& } \\
\text { Ebimobowei, 2012) }\end{array}$ \\
\hline $\begin{array}{l}\text { Monitoring and } \\
\text { evaluation }\end{array}$ & $\begin{array}{l}\text { - Regularly monitor and evaluate tax collection and } \\
\text { administration } \\
\text { - Continuously improve the services to ensure the } \\
\text { quality of work } \\
\text { - Regularly monitor and evaluate tax officer's } \\
\text { performance }\end{array}$ & $\begin{array}{l}\text { (McCluskey \& } \\
\text { Franzsen, 2005; } \\
\text { Plesko, 2003) }\end{array}$ \\
\hline $\begin{array}{l}\text { Law } \\
\text { enforcement }\end{array}$ & $\begin{array}{l}\text { - Taking serious enforcement action against fail to } \\
\text { pay on time, late payment and non-compliance } \\
\text { - Strong enforcement of the law and increased } \\
\text { penalties must be applied speedily and forcefully } \\
\text { - Provide clear, simple and understandable rules, } \\
\text { guidelines and procedures for enforcement }\end{array}$ & $\begin{array}{l}\text { (Alias, 2002; } \\
\text { Gallagher, 2005; Al } \\
\text { Fahmey Abdul } \\
\text { Rahim, 2010) }\end{array}$ \\
\hline $\begin{array}{l}\text { Leadership } \\
\text { style }\end{array}$ & $\begin{array}{l}\text { - Help the staff to make working on their tasks more } \\
\text { pleasant }\end{array}$ & $\begin{array}{l}\text { ( Al Fahmey Abdul } \\
\text { Rahim, 2010) }\end{array}$ \\
\hline
\end{tabular}




\begin{tabular}{|c|c|c|}
\hline & $\begin{array}{l}\text { - Encourage creativity and new ideas } \\
\text { - Frequently undertake market research for } \\
\text { formulating efficient policies regarding tax law } \\
\text { changes }\end{array}$ & \\
\hline $\begin{array}{l}\text { Private } \\
\text { participation }\end{array}$ & $\begin{array}{l}\text { - Engagement of private revenue collectors } \\
\text { - Privatization of certain areas in tax administration } \\
\text { - Translate land laws and regulations into local } \\
\text { languages to ensure equal participation from } \\
\text { various levels of citizen }\end{array}$ & (Holcombe, 2006) \\
\hline $\begin{array}{l}\text { Public } \\
\text { enlightenment }\end{array}$ & $\begin{array}{l}\text { - Increase public enlightenment to maintain } \\
\text { community confidence } \\
\text { - Adequately inform taxpayers on the procedure and } \\
\text { responsibilities for paying their taxes } \\
\text { - Increase campaigns on utilization of tax revenue by } \\
\text { tax department to encourage tax payment }\end{array}$ & $\begin{array}{l}\text { (Abiola \& Asiweh, } \\
\text { 2012; Kasipillai, } \\
\text { Aripin, \& Amran, } \\
\text { 2003; Nwanna \& } \\
\text { Richards, 2016) }\end{array}$ \\
\hline $\begin{array}{l}\text { Rules and } \\
\text { regulations }\end{array}$ & $\begin{array}{l}\text { - Law, regulations and processes are fair, besides } \\
\text { being implemented and enforced without any } \\
\text { biases } \\
\text { - Regulations and policies are enforceable to } \\
\text { taxpayers } \\
\text { - Policies and procedural manual forming part of } \\
\text { knowledge are frequently updated }\end{array}$ & $\begin{array}{l}\text { (Gill, 2000; James } \\
\text { and Nobes, 2000; } \\
\text { Sindzingre, 2007) }\end{array}$ \\
\hline Service delivery & $\begin{array}{l}\text { - Services are provided via automation } \\
\text { - Answer any enquiries within a reasonable period } \\
\text { - Conduct client surveys }\end{array}$ & $\begin{array}{c}\text { (Walker, 1995; } \\
\text { Wisniewski, 2001) }\end{array}$ \\
\hline $\begin{array}{l}\text { Tax audit } \\
\text { practice }\end{array}$ & $\begin{array}{l}\text { - Not to take a very long time in handling tax audit } \\
\text { and inspection } \\
\text { - Produce comprehensive audit report } \\
\text { - Audit procedure is transparent and clear }\end{array}$ & $\begin{array}{c}\text { (George \& Diavastis, } \\
2016)\end{array}$ \\
\hline Tax agencies & $\begin{array}{l}\text { - Maintaining agency good and positive image } \\
\text { - Deliver all of the required services at one } \\
\text { geographical area } \\
\text { - Introduce counter offices and a numbering system } \\
\text { for client's arrival }\end{array}$ & $\begin{array}{c}\text { (Appah \& } \\
\text { Oyandonghan, } \\
\text { 2011; Huang \& Rios, } \\
\text { 2016) }\end{array}$ \\
\hline $\begin{array}{l}\text { Tax collection } \\
\text { strategy }\end{array}$ & $\begin{array}{l}\text { - Assess correct payment rate or value } \\
\text { - Provide skillful revenue collectors to perform their } \\
\text { job } \\
\text { - Payment of taxes anywhere }\end{array}$ & $\begin{array}{c}\text { (Bird \& Zolt, 2008; } \\
\text { Chatama, 2013) }\end{array}$ \\
\hline Use of ICT & $\begin{array}{l}\text { - Remote access to land information using internet } \\
\text { technology } \\
\text { - Apply appropriate system for collecting tax } \\
\text { - Powerful monitoring tool }\end{array}$ & $\begin{array}{l}\text { (Bird \& Zolt, 2008; } \\
\text { Chatama, 2013; } \\
\text { Machupa et al., } \\
\text { 2011) }\end{array}$ \\
\hline $\begin{array}{l}\text { Tax reforms } \\
\text { and } \\
\text { amendment }\end{array}$ & $\begin{array}{l}\text { - Restructure and update the existing forms to } \\
\text { facilitate effective tax administration and better } \\
\text { tax compliance } \\
\text { - Definition, objectives and purposes of tax are }\end{array}$ & $\begin{array}{l}\text { (Keen \& Slemrod, } \\
\text { 2017; Keen et al., } \\
\text { 2015) }\end{array}$ \\
\hline
\end{tabular}




\section{clearly explained \\ - Formulate a clear tax strategy}

Above factors are based on the literature review

\section{Conceptual Model for Efficiency in Tax Administration}

The conceptual framework as a visual or written product, one that "explain, either graphically or in narrative form, the key things to be studied, the major factors, concepts or variables and the supposed the relationship among them" (Miles \& Huberman, 1994).

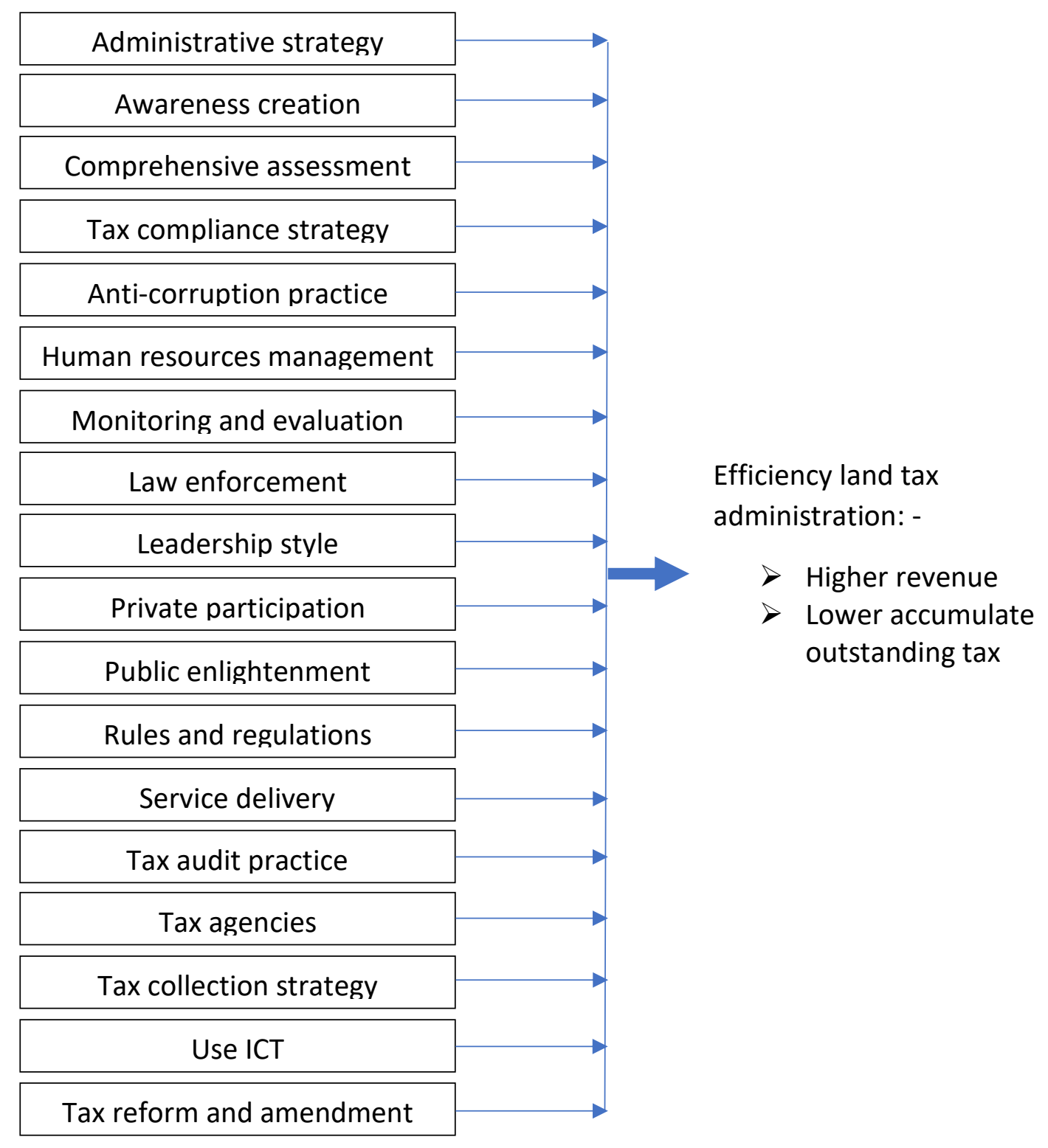

Figure 3. Conceptual model for efficiency in tax administration (Source: Author's).

This conceptual framework is a diagrammatic represent of the variables that influence tax administration efficiency as determined by the tax efficiency factor and as discussed in this study. The dependent variable is tax administration efficiency factors which are the variable of primary interest in which the variance is attempted to be explained by the eighteen 
variables. The eighteen independent variables and the dependent variable are as indicated in the figure below. The conceptual framework of this study is presented above.

Figure 3 presents the conceptual model which illustrates the foundation on which the entire project is based. It is a logically developed, described and elaborated network of associations among the variables deem relevant to the problems situation and identified through the literature survey.

\section{Conclusion}

Tax administrations in developing countries need to improve their performance, and this can be done through efficient administration. The main role of a tax administration is to collect tax revenue. Poor tax collection in developing countries has limited the capacity of their governments to raise revenues for various purposes. These issues indicate the need to improve the efficiency of tax administrations. As noted at the outset, this brief focuses on how to conduct an efficiency analysis of tax administration and collection that provides useful information to authorities and the tax payers'. The efficiency tax administration includes several factors potentially influencing the performance. The theoretical review of this study highlighted a conceptual framework for efficiency tax administration and collection, and its potential application to land tax performance assessment in other countries. Eighteen elements of land tax administration and collection efficiency were identified, namely: administrative strategy, awareness creation, comprehensive assessment, compliance strategy, anti-corruption practice, human resources management, monitoring and evaluation, law enforcement, leadership style, private participation, public enlightenment, rules and regulations, service delivery, tax audit practice, tax agencies, collection strategy, use of ICT, and tax reforms and amendment. The Framework's purpose is to assist the authorities in improving the land tax systems. Given the findings from the study, it is recommended that government should put a strategic mechanism in place to land tax reforms by adopting the proposed framework.

\section{Acknowledgement}

Sincere gratitude to the Ministry of Higher Education of Malaysia especially Mybrain 15 for providing the scholarship that facilitated my study at Doctor of Philosophy level (Land Administration and Development) at Universiti Teknologi Malaysia (UTM) Skudai JB, Malaysia. Also, I'm extremely grateful to my PHD supervisor, Dr Salfarina Samsudin, who helped tremendously with expert advice, criticisms and constructive comments which guided the research's paper direction and value-added the overall quality of the journal paper.

\section{Corresponding Author}

Siti Norfaizah Sahari

Department of Real Estate, Faculty of Built Environment and Surveying, Universiti Teknologi Malaysia, 81310 Skudai, Johor, Malaysia.

Email: snorfaizah.utm@gmail.com 


\section{References}

Abiola, J., \& Asiweh, M. (2012). Impact of Tax Administration on Government Revenue in a Developing Economy - A Case Study of Nigeria. International Journal of Business and Social Science, 3(8), 99-113.

Akintoye, I. R., \& Tashie, G. A. (2013). The Effect of Tax Compliance on Economic Growth and Development in Nigeria, West - Africa. British Journal of Arts and Social Sciences, 11 (li), 222-231.

Alabede, J. O., Ariffin, Z. B., \& Idris, K. M. (2011). Determinants of Tax Compliance Behaviour: A Proposed Model for Nigeria. International Research Journal of Finance \& Economics, 78(78), 121-136.

Alias, B. (2002). Analysis Factor That Contribute to The Accumulation of Uncollected Rates in Local Authorities in Malaysia, Unpublish PhD Thesis, Universiti Teknologi Malaysia.

Alm, J., Martinez, V. J., \& McClellan, C. (2016). Corruption and Firm Tax Evasion. Journal of Economic Behavior and Organization, 124, 146-163.

Anyaduba, J. O. (2018). Sensitivity of Nigeria's Taxable Capacity to Government's Tax Efforts. Finance India, 32(2), 507-518.

Appah, E., \& Oyandonghan, J. K. (2011). The Challenges of Tax Mobilisation and Management in The Nigerian Economy. Journal of Business Administration and Management, 2(6), 128-136.

Auerbach, A. J., \& Hines, J. R. (2002). Taxation and Economic Efficiency. In Handbook of Public Economics (Vol. 3).

Australian Taxation Office. (2007). "Guide for Researchers. Literature Review: Measuring Compliance Effectiveness."

Bartuševičienè, I., \& Šakalytė, E. (2013). Organizational Assessment: Effectiveness Vs. Efficiency. Social Transformations in Contemporary Society, 2013(1), 45-53.

Baurer, L. I. (2005). Tax Administrations and Small and Medium Enterprises (SMEs) in Developing Countries.

Bird, R. M., \& Zolt, E. M. (2008). Technology and Taxation in Developing Countries: From Hand to Mouse. In SSRN.

Chan, C. W., Troutman, C. S., \& O'Bryan, D. (2000). An Expanded Model of Taxpayer Compliance: Empirical Evidence from The United States and Hong Kong. Journal of International Accounting, Auditing and Taxation, 9(2), 83-103.

Chatama, Y. J. (2013). The Impact of ICT On Taxation: The Case of Large Taxpayer Department of Tanzania Revenue Authority. Developing Country Studies, 3(2), 91-101.

Connolly, S., \& Munro, A. (1999). Economics of the Public Sector. Prentice Hall Europe.

Crandall, W., \& Bodin, J.-P. (2005). Revenue Administration Reform in Middle Eastern Countries. IMF Working Papers, 48.

Dale, P. F., \& McLaughlin, J. D. (1999). Land Administration. Oxford University Press.

Ding, C. (2003). Land Policy Reform in China: Assessment and Prospects. Land Use Policy, 20(2), 109-120.

Djankov, S., Ganser, T., McLiesh, C., Ramalho, R., \& Shleifer, A. (2010). The Effect of Corporate Taxes on Investment and Entrepreneurship. American Economic Journal: Macroeconomics, 2(3), 31-64.

Gallagher, M. (2005). Benchmarking Tax System. Central Europe, 144, 125-144.

Ganesh, M., \& Indradevi, R. (2015). Importance and Effectiveness of Training and Development. Mediterranean Journal of Social Sciences, 6(1), 334-338. 
Gauthier, B., \& Reinikka, R. (2006). Shifting Tax Burdens Through Exemptions and Evasion: An Empirical Investigation of Uganda. Journal of African Economies, 15(3), 373-398.

George, D. S., \& Diavastis, I. (2016). Tax Audit Effectiveness in Greek Firms: Tax Auditors Perceptions. Journal of Accounting and Taxation, 7(7), 123-130.

Gill, J. B. S. (2000). Diagnostic Framework for Revenue Administration. Technical Paper, (472), 68.

Hastuti. (2014). Tax Awareness and Tax Education: A Perception of Potential Taxpayers. International Journal of Business, Economics and Law, 5(1), 9.

Holcombe, R. G. (2006). The Tax Cost of Privatization. Southern Economic Journal, 56(3), 732. Huang, J., \& Rios, J. (2016). Optimal Tax Mix with Income Tax Non-compliance. Journal of Public Economics, 144, 52-63.

James, S., \& Nobes, C. (2000). The Economics of Taxation. Essex: Pearson Education Limited.

Kasipillai, J. N. (2003). The Influence of Education on Tax Avoidance and Tax Evasion. eJournal of Tax Research, 1(2), 134-146.

Kasipillai, J., Aripin, N., \& Amran, N. A. (2003). The Influence of Education on Tax Avoidance and Tax Evasion. 1(2), 134-146.

Kasipillai, J., Baldry, J., \& Rao, P. D. (2000). Estimating the Size and Determinants of Hidden Income and Tax Evasion in Malaysia. Asian Review of Accounting, 8, 25-42.

Kayuza, H. (2006). Real Property Taxation in Tanzania: An Investigation on Implementation and Taxpayer Perceptions. Sweden.

Keen, M., \& Slemrod, J. (2017). Optimal tax administration. Journal of Public Economics, 152, 133-142.

Keen, M., Toro, J., Baer, K., Perry, V., Norregaard, J., Ueda, J., Wingender, P. (2015). Current Challenges in Revenue Mobilization: Improving Tax Compliance. IMF Working Paper, (April), 1-79.

Hussein, K. M. (2006). Capacity Building Challenges in Malawi's Local Government Reform Programme. Development Southern Africa, 23(3), 371-383.

Kirchler, E., \& Wahl, I. (2010). Tax Compliance Inventory: TAX-I Voluntary Tax Compliance, Enforced Tax Compliance, Tax Avoidance, and Tax Evasion. Journal of Economic Psychology, 31(August 2016), 331-346.

Leibenstein, H. (2011). X-Efficiency Theory. In the New Palgrave Dictionary of Economics.

Machupa, O., Otaigo, E., Koloseni, D., \& Shimba, F. (2011). Assessing the Factors Influencing Information Technology Investment Decisions. Communications in Computer and Information Science, 385-399.

McCluskey, W. J., \& Franzsen, R. (2005). An Evaluation of The Property Tax in Tanzania. Property Management, 23(1), 43-69.

Miles, M., \& Huberman, M. (1994). Data Management and Analysis Methods. Handbook of Qualitative Research, 428-444.

Al Fahmey Abdul Rahim, M. Y. (2010). Sources of Quit Rent Arrears. Unpublish PhD Thesis Universiti Teknologi Malaysia Skudai.

Noh, H. D. (2008). Hasil Cukai Tanah Negeri Kedah: Sejauh Manakah Kadar Cukai Tanah Negeri Kedah Bertepatan Dengan Konsep Cukai Mampu Bayar Oleh Pemilik Tanah. Universiti Teknologi Malaysia: Unpublish Thesis Sarjana.

Nwanna, G., \& Richards, D. (2016). The Imperative of Basic Tax Education for Citizens. American Journal of Business Education (AJBE), 3(9).

Ogbonna, G. N., \& Ebimobowei, A. (2012). Impact of Tax Reforms and Economic Growth of Nigeria: A Time Series Analysis. Current Research Journal of Social Sciences, 4(1), 62-68. 
Plesko, G. A. (2003). An Evaluation of Alternative Measures of Corporate Tax Rates. Journal of Accounting and Economics, 35(2), 201-226.

Pommerehne, W. W., \& Hannemann, W. H. (2004). Tax Rates, Tax Administration and Income Tax Evasion in Switzerland. Public Choice, 88(1-2), 161-170.

Ratcliffe, J. (1976). Land Policy: An Exploration of the Nature of Land in Society. London: The Anchor Press Ltd.

Remali, A. M., Qusyairi, A., Rahim, A., Noorzila, B. S., Mahmud, M. S., Syafiqah, N., \& Shah, M. (2015). Factors Affecting the Tax Non-Compliance Attitude. National Symposium \& Exhibition on Business \& Accounting, (Nseba Iv), 1-7.

Saad, N. (2014). Tax Knowledge, Tax Complexity and Tax Compliance: Taxpayers' View. Procedia - Social and Behavioral Sciences, 109, 1069-1075.

Sahari, S. N., \& Samsudin, S. (2019). Literature Review on Performance Efficiency and Effectiveness in Tax Administration and Collection System. In GBES 2019, UTM Johor Baharu, Malaysia:24-26 June 2019.

Sahari, S. N., Samsudin, S., Bujang, A. A., \& Jiram, W. R. (2018). A Review of Key Issues and Challenges in Malaysian Land Taxation to Enable Good Tax System in Land Administration. Journal of the Malaysian Institute of Planners, 9th IRERS 2018, 23-25 April 2018, INSPEN, Selangor.

Sahari, S. N., Samsudin, S., Bujang, A. A., Suratman, R., Rahman, M. S. A., \& Jiram, W. R. A. (2020). General Review on Malaysia Land Taxation. International Journal of Academic Research in Business and Social Sciences, 10(3), 554-569.

Sahari, S. N., Samsudin, S., Bujang, A. A., Suratman, R., Rahman, M. S. A., \& Jiram, W. R. A. (2020). Review on Malaysia tax performance: Rates and land tax. International Journal of Psychosocial Rehabilitation, 24(3), 694-716.

Sapiei, N., Abdullah, M., \& Ismail, K. (2013). A Qualitative Findings of Tax Compliance Burden: Analysis of Tax Preparers Survey. American Journal of Economics, 3(i), 1-5.

Shemdoe, E. E. R. (2015). Factors Affecting Collection of Revenues in Muleba District Council in Kagera Region Tanzania: The Case Study of Muleba District Council in Kagera Region. Open University of Tanzania.

Sindzingre, A. (2007). Financing the developmental State: Tax and revenue issues. Development Policy Review, 25(5), 615-632.

Sommerfeld, R. M., Brock, H. R., \& Anderson, H. M. (1981). An Introduction to Taxation. New York: Harcourt Brace Jovanovich.

Tessema, M. T., \& Soeters, J. L. (2006). Practices and Challenges of Converting Former Fighters into Civil Servants: The Case of Eritrea. Public Administration and Development, 26(4), 359-371.

The Australian Government's Overseas Aid Program. (2001). Undertaking Land Administration Projects: Sustainability, Affordability, Operational Efficiency and Good Practice Guidelines.

Vlassenko, I. (2001). Evaluation of The Efficiency and Fairness of British, French and Swedish Property Tax Systems. Property Management, 19(5), 384-416.

Walker, J. L. (1995). Service Encounter Satisfaction: Conceptualized. Journal of Services Marketing, 9(1), 5-14.

Whait, R. B. (2012). Developing Risk Management Strategies in Tax Administration: The Evolution of The Australian Taxation Office's Compliance Model. eJournal of Tax Research, 10(2), 436-464. 
Williamson, I., Enemark, S., Wallace, J., \& Rajabifard, A. (2010). Land Administration for Sustainable Development. Sustainable Development, (April), 11-16.

Wisniewski, M. (2001). Using SERVQUAL To Assess Customer Satisfaction with Public Sector Services. Managing Service Quality: An International Journal, 11(6), 380-388.

Yang, Y., Ge, E., \& Barns, R. (2011). Towards Effective and Efficient Identification of Potential Tax Agent Compliance Risk: A Stratified Random Sampling Approach. eJournal of Tax Research, 9(1), 116-137. 